\title{
Diacylglycerol Kinase Alpha
}

National Cancer Institute

\section{Source}

National Cancer Institute. Diacylglycerol Kinase Alpha. NCI Thesaurus. Code C112503.

Diacylglycerol kinase alpha (735 aa, $\sim 83 \mathrm{kDa}$ ) is encoded by the human DGKA gene. This protein is involved in the negative regulation of second messenger signaling through lipid phosphorylation. 